\title{
Small innovative company's valuation within venture capital financing of projects in the construction industry
}

\author{
Alexander Bril ${ }^{1 *}$, Olga Kalinina, and Igor Ilin $^{1}$ \\ ${ }^{1}$ Peter the Great Saint-Petersburg Polytechnic University, Polytechnicheskaya, 29, St.Petersburg, \\ 195251, Russia
}

\begin{abstract}
The article is focused on the pressing and debatable challenge of venture capital business - the valuation of the company aimed to ensure the process of "buy-back" in the preparation of the agreement on the financing of start-ups in the Russian Federation. Exactly this stage of venture project evaluation occurs to be the most arguable among investors and founders of the company, because up to $40 \%$ of transactions fail at this stage. The materials of the article provide a set of simple methods to assess the value of the company, which is actually feasible in the early stages of design. The article considers the overall situation of development in recent years and the classification of the main types of external venture business in Russia, depending on the financial resources discussed to justify the proposals. The proposals are based on the experience of the authors in the field of business planning innovative projects and analysis of small innovative enterprises schemes based on investment stages. In the article, there is an example of economic indicators monitoring and calculation on start-up of special modules of electric systems, working in the construction business.
\end{abstract}

\section{Introduction}

Venture business is one of the most effective ways to finance innovation projects. Venture capital funds invest in promising innovative little known organization on its earliest stages of development, when it is not remarkable and has not yet completed the implementation of the "business idea" underlying its business. Investment period is three to seven years. Venture Fund in exchange for its investment receives a share in the authorized capital of the Innovative Company and after a certain period comes out of it by the "buy-back": sells its stake in the open market or to a strategic investor.

Some of these projects are unprofitable or low profitable, but some of them bring significant revenue and earnings even excess profit. In this regard, the average rate of return of venture funds is $25-30 \%$, far exceeding the revenues of conventional investment projects with a rate of $5-10 \%$.

The Russian venture funds emerged in the early 90s. Economic restructuring and privatization processes have caused a sharp increase in interest in the private equity market

*Corresponding author: bar.bril@yandex.ru 
in Russia from various investors and, consequently, affected dynamic start of venture business. This activity is supported by some large companies, also venture capital funds are created and innovation development networks [1-4]. The main objectives of these organizations are to find new and effective ideas - innovations and the creation of conditions for their transformation into highly profitable businesses.

After 2010, large number of venture capital funds starts to actively work in the country. Thus, in the framework of public-private partnerships, together with the Russian Venture Company 6 venture funds with an investment volume of more than 17 billion rubles are formed. These funds are such as the VTB Venture Fund, Bioprocess, Maxwell Biotech and others, each with a volume of about 3 billion rubles. A large number of regional venture funds are emerged. The largest of them, with a capital of 800 million rubles - a venture capital fund of Moscow, the Krasnodar region, Tatarstan, St. Petersburg (400 million rubles). Private venture capital firms are effectively operating, these are Runa Capital, Russian Ventures, Almaz Capital, ru-Net Ventures, IMI.VC and many others.

Russian Venture fund named Prostor Capital and data analytics company Data Insight published the results of its research "Venture Barometer Russia 2016" on the status of Russian venture capital market in 2016. Experts interviewed 37 participants of Russian venture capital market - investors, foundations, partners, business angels and others. Representatives of 30 companies are among the respondents - more than $70 \%$ of active investors in the country. $92 \%$ of respondents responded that they invested in $2016,70 \%$ that they invested in Russian projects, 31\% - invested exclusively in the Russian market. The results showed that the market activity is presented by all the main categories of investors. The most active investors called private foundations.

A key trend in the development of venture business in 2016 in a study is the access to international markets and work with foreign assets $(72 \%, 90 \%$ in 2015$)$. The leading driver of the market in recent years up to 2015 was considered to be a large size of the Russian Internet audience. Researchers believe that in 2016 the market driver changed. It is the cheapest skilled labor and a large number of qualified professionals in Russia now.

The most common business venture financing mechanism is a system of a joint venture with the "buy-back". To implement this methodology, it is necessary to determine the value of the company, the amount of authorized capital, the cost of the joint venture at the beginning of financing and at the time of the agreed repayment date. At this stage, screenings of innovation often occurs due to the inability to obtain consistent estimates. Exactly this stage of venture project evaluation occurs to be most arguable among investors and founders of the company, significant portion of transactions fail at this stage The literature suggests a large number of methods for calculating the value of the company at various stages of development. Many methods are quite complex and require basic of information that at the start-up stage can not be sufficiently reliable. This article is about methodology of selection of methods to calculate the value of the company at different stages of its development.

\section{Method}

Venture financing is a long-term direct investments in small innovative enterprises with a high or relatively high risk in order to obtain a significant profit in the period from 3 to 7 years. This activity is supported by some large companies, and venture capital funds and innovative development networks are created [1-4]. The main objective of these organizations is finding new and effective ideas - innovations and the creation of conditions for their transformation into highly profitable businesses.

The main types of external venture financing are presented in the Table 1 . 
Table 1. The integrated circuit of venture business varieties, compiled by the authors.

\begin{tabular}{|c|c|c|}
\hline \multicolumn{3}{|c|}{ External Venture business } \\
\hline \multicolumn{2}{|c|}{$\begin{array}{c}\text { Private investors } \\
\text { (business angels) }\end{array}$} & $\begin{array}{c}\text { Specialized companies } \\
\text { (venture funds) }\end{array}$ \\
\hline $\begin{array}{l}\text { Business Idea } \\
\text { ("seed" stage) }\end{array}$ & $\begin{array}{c}\text { Complete research ("start- } \\
\text { up" stage) }\end{array}$ & $\begin{array}{c}\text { Small company with } \\
\text { finance and qualified staff } \\
\text { deficit }\end{array}$ \\
\hline
\end{tabular}

The development of domestic venture capital business is carried out mostly in large enterprises at the expense of the idea initiators resources. External venture financing is proceeded by raising funds from external sources: investment, insurance, charity and pension funds, State resources and private investors. Organization is carried out either through the creation of venture capital funds, or by individual activity of entrepreneurs, called business angels. At the same time, if not going into the industry details, the most widely used are three types of funding: applied research ("seed" stage according to the USEuropean classification of innovation development stages), the start-ups in the same classification and small innovative enterprises with lack of financial resources.

Venture capital investments for funding decisions require a feasibility study. It is necessary to take into account two main points. The first - is the availability of information for plan calculations, that is fundamentally different to those, for example, objects of funding as "seed" or existing small business. And the second - the funding decision rules of venture capital funds, industrial companies or business angels. If the business angel - a private investor decides whether to participate in innovative projects or not mostly based on personal experience and risk assessment, then venture capital funds have specially designed guidelines for the selection of investment projects. The methodology for assessing the effectiveness of future investments only for venture capital funds is presented in this paper.

Venture companies income formed by the "buy-back" system, i.e., the sale of joint venture company shares in innovative enterprise after its 3-7 years.

Diagram of the small innovative company organization with the release of the fund and repurchase stages is presented in Figure1.

The scheme contains the following legend:

VF - Venture fund, AMC - asset management company, E - entrepreneur, PN Primary Negotiations, BofJV - beginning of joint venture, InE- Innovative enterprise, B-B - buy-back procedure;

1 - primary selection of innovative ideas and entrepreneurs procedure;

2 - procedure for the first meeting and clarification of entrepreneur and his company background;

3 - due diligence, auditing, financial analysis and evaluation of actual and planned enterprise value, reconciliation of the data and preparation for new innovative businesses registration procedure;

4 - organizational issues, the initial funding in accordance with the business plan and start of joint venture;

5 - financing a new venture in accordance with the plan and the operational schedule, experts involvement in innovation management, joint organization of production and sales;

6 - attraction of credit funds for the development of the company;

7 - preparation and organization of joint venture share buy-back in innovation company. 


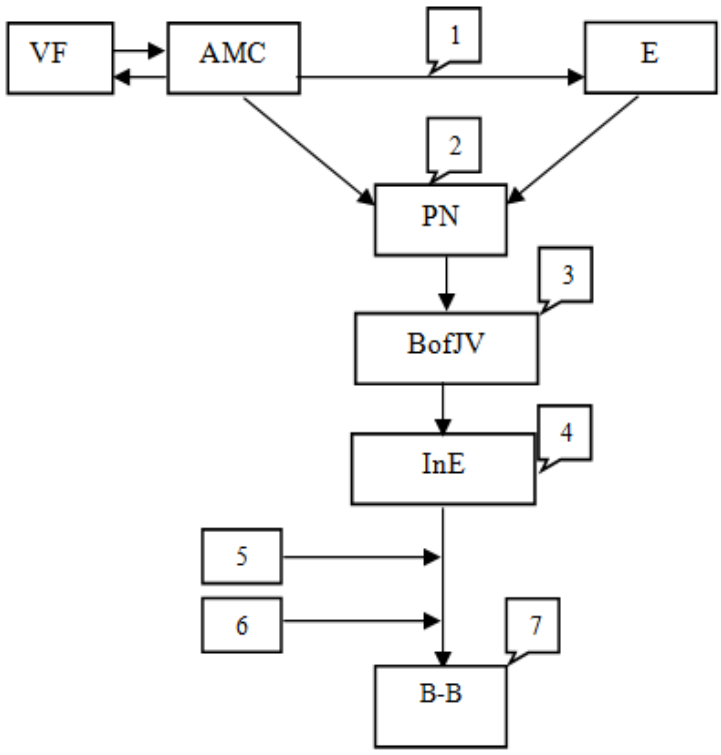

Fig. 1. The scheme of small innovative enterprise organization and operation, compiled by the authors.

Organizational and technological and economic issues are solved at each stage. From the financial and economic point of view, enlarged or preliminary business plans are considered at the first stage. The second stage specifies the initial information on the project and the applicant company, in the case of agreed estimates reception joint work program is developed.

The third step is to determine the value of the applicant company, the amount of shareholders equity, the cost of the joint venture at the beginning of financing and at the time of the agreed repayment date. This is the most difficult part of venture company and entrepreneur negotiations. A revised business plan for the development of joint venture should be developed and agreed in this process, which is a basis for further sources of financing, order and buy-back price. Innovation screenings occurs often at this stage due to inability to obtain consistent estimates. According to experts [1], it is this stage of venture project evaluation where most contention between investors and company founders appears, and at this stage breaks down up to $40 \%$ transactions. A sign of reaching an agreement is considered to be a divergence of views on the value of the company not more than $20 \%$. The main objective of the feasibility study and analysis of the company's value lies in the achievement of such an agreement.

"Buy-back" system is realized through three main ways:

- Management buyout (sale of venture capital company shares to existing shareholders and management);

- External repurchase (sale of venture capital company shares to outside investors);

- The sale of venture capital company shares by initial public offering (IPO).

\section{Results}

The most difficult issue of venture business is the selection procedure for innovation financing. Effective organization of this process involves the forced screening and presentation to funding the best and most promising ideas in the field of IT. 
Experience and statistics show that out of several thousand variants of innovative ideas and entrepreneurs primary selection for the procedure of the first meeting and data clarification remains about 700 - 800 options. After this stage another 500 options are eliminated. In the end, after the initial joint activities (due diligence - Procedure 3, Figure 2) stays about 12 to 14 options of innovative companies to invest.

The literature offered and used in practice a large number of methods and approaches for determining the value of the company and venture investors attraction [6]. The objective is to systematize these methods in relation to different stages of venture capital financing and, most importantly, in relation to the different level of innovation. Radical innovations associated with the new worldwide or Russian products and processes that are more risky and, therefore, the results are more difficult to predict. For such innovations plan calculations of cost indicators should be led on the basis of simple aggregated methods. For simple innovations related to substantial and sometimes with minor modifications of known processes and products more detailed methods can be used.

Experience allows to define the basic requirements for the content and parameters of financial and economic calculations at all selection stages and joint work of IT-innovative enterprises (according to Figure 2).

In the first stage - the procedure of primary selection of innovative ideas and entrepreneurs - the main criterion is the idea of the project. Nevertheless, financial and economic part of the business plan is considered almost always. It is advisable to limit calculation by simple indicators of commercial efficiency (simple payback period and rate of return), focusing on the plan calculations reliability on forecasted timing and volume of sales of new products. In these matters the owners of ideas tend to increased optimism. Business plan cost indicators are calculated based on the cost approach. Risk assessment at this stage, should be carried out based 4- 5situations analysis, including optimistic and pessimistic variants. The second stage - the first meeting and data clarification about the entrepreneur and his company. Economic calculations during this procedure specify the accuracy of cost parameters and preliminary risk assessment. Availability of prototypes, laboratory test results, special statistics are important for this stage.

In the third phase - the procedure of due diligence - plan economic calculations of venture financing project are carried out. This is a basic step to determine the actual cost of the innovative business before venture capital financing (pre-money) and justification of future innovative enterprise cost for repurchase price approval.

This step should be divided into two sub-step 3.1. and 3.2. The calculations in sub-step 3.1 aimed to determine the future value of the company subject to its independent development, without the use of venture capital financing.

Sub-step 3.2 is focused on the future value of innovation company calculation based on venture capital attraction, the resulting synergy effects and the effect of attracting specialists of the management company MC (specialists in innovation management, production organization and sales of new products). An important question here is dependence of the new innovative enterprise value (procedure 4 Figure 2), not only from sum of capital, but also from the advice of experienced investors. The results of studies [1], [3], [4] shows that $40 \%$ of the sample investors who were passive, failed more often than active investors; and the more active investor is in terms of the frequency of interaction with the owner, the more likely investment led to positive results.

Using two approaches to assess the future value of the company (with and without venture capital) allows to use the method of comparative effectiveness in establishing the agreed price of buy-back and making decision on venture capital financing in innovative enterprise (see Further example of the calculation for the special electronic transmitters module equipment startup). 
Sub-step 3.1 defines the value of pre-money based on the cost approach after audit and evaluation of existing businesses financial condition. Calculation of future value (compared to the cost of repurchase) is based on income approach. The initial amount is determined by the pre-money, discount rate is set based on the profitability of the existing assets of the enterprise or as a cumulative value based on the CAPM model. If there is a sales statistics, and IPO of similar enterprises (by size and degree of innovation) future added value will be determined on the basis of a comparative approach.

In sub-step 3.2 the value of post-money should be determined, where appreciation of the company by attracting venture capital must be taken into account, synergies and participation of the management company in the future business development. Appreciation coefficients system is included in management companies regulatory framework of most developed venture capital funds. Determination of these factors can be associated with the franchises cost statistics in similar activities.

On the basis of the agreed post-money value, the calculation of the company value at the time of the planned exit of innovative enterprise venture fund can be started. There are several approaches for the assessment. The simplest of these are venture approach and method of future value. Venture approach is more simple in calculation, it does not require to determine future cash flow for calculation the company value. Venture capital average profitability statistics and planned rate of return of a particular venture capital fund is necessary to implement it. Then the value of the company's venture capital exit point $\mathrm{C}_{\mathrm{b}-\mathrm{b}}$ can be determined as follows:

$$
C_{b-b}=\text { post }- \text { money } \cdot(1+i)^{n}
$$

Where $i$ - comparison rate, taken at the level of the planned fund rate of return based on average data ( 20 - $30 \%$ per year);

$n$ - planning period in years.

Comparison rate determination is a key calculation moment, requires special justification. Buy-back cost is determined by the planned share of venture fund in a new enterprise shareholders' equity. Future value method requires more detailed and timeconsuming calculation. It is based on the construction of tables and graphs of planned cash flows and takes into account the credit, income and payments of innovative enterprises in joint working process with a venture capital company. Comparison rate here is defined as the weighted average cost of capital used for the project WACC. Risk assessment is carried out based on a sensitivity analysis to changes in the future value of the planned sales volumes, costs and comparison rate. As a result of economic calculations in the third stage of venture capital financing quite a broad base of financial and economic indicators for harmonization and clarification is created. The relatively simple algorithms of presented methods and existing software products allows to focus on future value monitoring on ensuring the reliability of the source data. Table 2 presents proposed methods of calculating the value indicators in a systematic way.

Table 2. Methodsforcalculatingthevalueofthecompany at different stages.

\begin{tabular}{|c|c|c|c|}
\hline \multirow{2}{*}{ Stage } & \multicolumn{3}{|c|}{ Methods for calculating the value of the company } \\
\cline { 2 - 4 } & «pre- money» & «post - money» & At the buy-back moment \\
\hline 3.1 & Cost-based & equals«pre - money» & $\begin{array}{c}\text { Profitable } \\
\text { Comparative }\end{array}$ \\
\hline 3.2 & Cost-based & Regulatory appreciation & $\begin{array}{c}\text { Venture } \\
\text { Future value }\end{array}$ \\
\hline
\end{tabular}


This payment system allows to create an information base for clarification and consistent assessment of actual and planned cost of the enterprise, the organizational issues solution and preparation for new innovative enterprises registration.

As an example of the proposed economic calculation method, consider a start-up for the production of special transceiver modules to existing small business.

The company has the equipment, personnel and documentation for small-scale production units. The value of assets, determined on the basis of cost method "pre money» is 1.6 million rubles.

Analysis of the market and competitors indicated that the planned sales could reach over the next three years, from 3 to 4 thousand pcs. per year, with selling prices from 45 to 55 thousand rubles per unit.

The calculations of the enterprise capacity show that production of new units in the amount of 250 pieces can be mastered per year at a cost of 49 thousand rubles per unit. By the third year the production volume can be adjusted (without additional major investment) up to 320 pcs. at a cost of 48 thousand rubles per unit.

Venture capital fund, which is ready to invest in the project is not more than $75 \%$ of its total cost is found.

Further calculations show that the acquisition of special equipment for the installation of elements and arrangement of additional workplaces in the amount of $4.5 \mathrm{mln}$. rubles can increase plant capacity to 1100 units by the third year of the project. Production cost of one unit at the same time can be reduced in the first year to 45 thousand rubles per unit and in a third year to 43.5 thousand rubles per unit.

There is a need to conduct economic calculations and risk assessment in order to determine a more effective solution to the current enterprise: organization of independent small-scale production or raising venture capital fund to increase capacity by 3.5 times up to 1100 units per year.

In the first version (small-scale production) in accordance with the procedure «post money» equals «pre - money» 1.6 million rubles. On the basis of the income method future enterprise value $\mathrm{F}$ at the end of the third year is determined. Comparison rate is based on WACC model - weighted average cost of capital for the project - $20 \%$. The selling price of the module is stated at 50 thousand rubles per unit, first year sales volumes 250 units, second year - 300 units and in the third year - 320 units. In turn, production cost is 49.0 thousand rubles per unit, 48.5 thousand rubles per unit and 48.0 thousand rubles per unit. Depreciation rate is $25 \%$ per year, using the linear method of depreciation; respectively, the residual value of assets at the end of the third year is 0.4 million rubles. $F$ value is the following, million rubles:

$$
F=0.65 \cdot(1+0.20)^{2}+0.85 \cdot(1+0.20)+1.04+0.4=3.396
$$

To expand the value of the enterprise information at the end of the third year additional simple methods as " $50 \%$ of sales" or "fivefold profit on sales" could be used.

The volume of sales at the end of the third year of the project is $320 \times 50=16.0$ million rubles. Then the future enterprise value is estimated to be $16 \times 0.5=8$ million rubles. When calculating based on a "fivefold sales profit" method, future costs is 3.2 million rubles, which is largely consistent with the results of calculations by the income method.

In the second variant of development - creation of a joint venture with a venture capital fund - «post - money» will increase compared to «pre - money» by a factor of rise in price in accordance with the planned increase in return on sales by $6.3 \%$ and amount to $(1.6+$ $4.5) \times 1.063=6.48$ million rubles. 
Next similarly, value of the company at the end of the third year is counted by the venture method based on calculation of future value. The output of the joint venture business is planned for the end of the third year.

Venture capital investing into the project in the amount of 4.5 million rubles, with an average yield of $30 \%$ per year, expected value of its stake in the joint venture at the end of the third year should reach, million rubles:

$$
F=4.5 \cdot(1+0.30)^{3}=9.89
$$

If the share in the joint venture $4.5 /(4.5+1.6)=73.8 \%$, then the value of the joint venture at the end of the third year will be $9.89 / 73.8=13.4$ million rubles. And value of the share attributable to the company that owns innovation, will be $13.4-9.89=3.51$ million rubles. This value is calculated on the basis of venture capital approach, it is very slightly higher than the main results of the first embodiment from 3.2 to 3.396 million rubles.

To calculate the value of the company at the end of the third year on the basis of a methodology for assessing the future cost it is necessary to know the selling price of modules and build a cash flow schedule in accordance with the same calculation as in the first embodiment.

In the venture version of the project it is planned to reduce production cost of modules from an average of 48.5 thousand rubles per unit to 43.5 thousand rubles per unit or by $10.3 \%$. In this connection more competitive selling price of the module is planned 48.5 thousand rubles per unit, sales volumes in the first year - 900 units, in the second - 1000 units and the third -1100 units.

Production cost is 45.0 thousand rubles per unit, 44.0 thousand rubles per unit and 43.5 thousand rubles per unit respectively each year. The depreciation rate is $25 \%$ per year, using the linear method of depreciation respectively, the residual value of assets at the end of the third year is 1.62 million rubles. Comparison rate is adapted similarly to the first embodiment at a level of $20 \%$. $F$ value is the following, million rubles:

$$
F=4.72 \cdot(1+0.20)^{2}+6.12 \cdot(1+0.20)+7.22+1.62=22.98
$$

In this calculation the value of share attributable to the company-owner of innovation, will be $22.98 \times 0.262=6.02$ million rubles, which is much higher than the results of calculations of the first embodiment of the venture, and using venture method of calculation.

Enterprise cost information clarification at the end of the third year on the basis of the "50\% of the sales volume" or "fivefold sales profit" methods, provides additional data for analysis.

The volume of sales at the end of the third year of the project is $1100 \times 48.5=53.35$ million rubles. Then, future enterprise value is estimated at $53.35 \times 0.5=26.67$ million rubles.

When calculating on a "fivefold sales profit" future value will be 26.0 million rubles, which is greatly exceeds the results of the first option, and the calculations on venture basis. This is due to the fact that the calculation of future value is taken into account synergies from the creation of joint venture fund company.

A significant difference in the planned economic performance requires additional risk assessment and initial information adopted for calculation. The calculation results are shown in Table 3. 
Table 3. The results of economic calculations for the two development options.

\begin{tabular}{|l|c|c|}
\hline \multicolumn{1}{|c|}{ Project indicators } & \multicolumn{1}{|c|}{$\begin{array}{c}\text { The project of own } \\
\text { module production }\end{array}$} & Venture project \\
\hline $\begin{array}{l}\text { The volume of sales in the third year } \\
\text { of the project: }\end{array}$ & 320 & 1100 \\
units & 16.0 & 53.35 \\
million rubles & 15.36 & 47.85 \\
\hline $\begin{array}{l}\text { Production cost in the third year of } \\
\text { project, million rubles }\end{array}$ & 20 & 30 \\
\hline Comparison rate (cost of capital & & \\
WACC), \% & 1.6 & 1.6 \\
\hline Enterprise value & 1.6 & 6.48 \\
«pre - money», million rubles & 1.6 & 1.70 \\
\hline Enterprise value & & \\
«post - money», million rubles, & & 13.40 \\
including the share of the enterprise & - & 3.51 \\
\hline Enterprise value at the end of the third & - & 22.98 \\
year, million rubles & 3.396 & 6.02 \\
Venture method, & - & 26.67 \\
including the share of the enterprise & 8.0 & 6.99 \\
Income method (future value), & - & 26.0 \\
including the share of the enterprise & 3.20 & 6.812 \\
«50\% of sales volume» method, & - & 14.52 \\
including the share of the enterprise & 2.10 & 3.80 \\
«fivefold sales profit» method, & - & \\
including the share of the enterprise & & \\
\hline Net present value of the project NPV, & & \\
including the share of the enterprise & & \\
\hline
\end{tabular}

In addition to assessing the buy-back cost the effectiveness of the projects on the basis of determining the net present value NPV is also calculated in p. 7 Table 3. It confirms high efficiency of commercial joint venture with a venture capital fund.

It should be noted that two considered options for the development of special modules production can be supplemented by projects attracting "business angels", investors, bank lending or other methods of business organization. The presented method allows monitoring of planned situations with relatively simple compared to those recommended in the literature [5] economic indicators calculations.

\section{Conclusion}

The results of calculations for the two variants of special modules production and monitoring of economic indicators suggest the following conclusions for making a decision on the development of the enterprise:

1. It is necessary to carry out a refined risk assessment: the first variant is the lack of competitiveness, in the case of analogues and substitutes, due to the high cost and the planned sales price, in the second option - the possibility of organizing an effective buyback (or external management buy-out) at the high cost of the enterprise.

2. The essential difference in the planned value of the company at the time (the end of the third year of the project), obtained on the basis of different calculation methods, requires more detailed study of information sources, particularly with regard to the comparison rate (cost of capital for the project) and the expected production cost of new products. 
3. Monitoring of the project economic performance allows more soundly build organizational section of the business plan and calculate break-even in phases of the project.

\section{References}

1. Venture Accelerators: the Network of Innovation Development, 276(2013)

2. A. Popov, P. Roosenboom, Journal on Banking and Finance, 37, 4695-4710 (2013)

3. J. Woolley, A. Bruno, E. Carlson, Journal of Management for Global Sustainability, 2, 7-30 (2013)

4. J.P. Killing, International Business, 22, 132 (2013)

5. E.M. Rogova, M.A. Sapozhnikova, Economic sciences, 6-1(185), 150-158 (2013)

6. L.V. Nikolova, J.J. Kuporov, D.G. Rodionov, International Journal of Economics and Financial, 5 (3S), 68-72 (2015) 